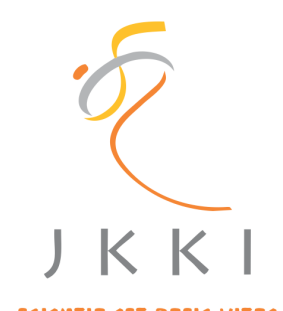

SCIEHTIA EST BASIC VITAE

\section{Jurnal Kedokteran dan Kesehatan Indonesia}

\author{
Indonesian Journal of Medicine and Health
}

Journal homepage: https://journal.uii.ac.id/JKKI

\title{
Primary repair of tetralogy of fallot and major aorto-pulmonary collateral arteries with suspected Noonan syndrome: A rare case
}

\author{
Heroe Soebroto ${ }^{1}$, Erdyanto Akbar*1, Arief Rakhman Hakim ${ }^{1}$ \\ ${ }^{1}$ Department of Thoracic Cardiac and Vascular Surgery, Faculty of Medicine, Universitas Airlangga/ Dr. Soetomo \\ Hospital, Surabaya, Indonesia
}

Case Report

\begin{tabular}{l}
\hline \\
\hline ART ICLE I NFO \\
\hline Keywords: \\
Tetralogy of Fallot, \\
Noonan Syndrome, \\
MAPCAS, \\
Primary Repair \\
*Corresponding author: \\
erdyantoakbar@gmail.com \\
\hline DOI:10.20885/JKKI.Vol11.Iss3.art13 \\
\hline History: \\
Received: December 19, 2019 \\
Accepted: December 17, 2020 \\
Online: December 31, 2020 \\
\hline Copyright @2020 Authors. \\
This is an open access article \\
distributed under the terms \\
of the Creative Commons At- \\
tribution-NonCommercial 4.0 \\
International Licence (http:// \\
creativecommons.org/licences/ \\
by-nc/4.0/).
\end{tabular}

\section{ABSTRACT}

Tetralogy of Fallot (TOF) is a congenital heart disease that includes ventricular septal defect (VSD), pulmonary stenosis (PS), right ventricular hypertrophy (RVH), and an overriding aorta. A cyanotic heart defect can develop aorto-pulmonary collateral (APCA) to supply underperfused pulmonary beds. Genetic syndromes can occur in $20 \%$ of patients with TOF. In developing countries, diagnosed genetic syndromes associated with heart defects have not been covered by health insurance, even though outcomes of primary repair remain unknown. This study reported a case of an 11-year-old boy with cyanosis since birth, dyspnoea on effort, growth delays, learning problems, scoliosis, micropenis, hypertelorism, exophthalmos, facial dysmorphism, cryptorchidism, and major aortopulmonary collaterals. The patient underwent an echocardiographic study. It showed VSD malalignment with overriding aorta of $48 \%$, critical pulmonary stenosis, and size of pulmonary arteries that were favourable for primary repair. Cardiac catheterization showed classic Fallot with normal coronary arteries and major aortopulmonary collateral arteries (MAPCA) arising. The patient underwent percutaneous coil embolization just before surgery. There was a problem during induction, the anaesthetist found that it was hard to place the ETT because there was membranelike covering the trachea. Next, a median sternotomy was conducted, and aortic cross-clamping was achieved. Right atriotomy was performed, and it provided exposure to the malalignment VSD. A longitudinal pulmonary arteriotomy was made to expose infundibular stenosis. Infundibulectomy was performed, and it reconstructed the MPA with a pericardial patch. The VSD was closed by using a PTFE patch. The patient was transferred to an ICU afterward. Post-operative echocardiography showed a good outcome, and 15 days after surgery the patient was discharged. It could be concluded that primary repair of TOF with MAPCAs and suspected Noonan syndrome was conducted successfully.

Tetralogy of Fallot (TOF) adalah penyakit jantung bawaan termasuk defek septum ventrikel (VSD), stenosis paru (PS), hipertrofi ventrikel kanan (RVH), dan overiding aorta. Cacat jantung sianotik dapat mengembangkan aorto-pulmonary collateral (APCA) untuk memasok vaskularisasi pada pulmonary bed yang kurang vaskularisasi. Sindrom genetik dapat terjadi pada 20\% pasien dengan TOF. Di negara berkembang, sindrom genetik yang didiagnosis terkait dengan kelainan jantung belum ditanggung oleh asuransi kesehatan, dan hasil koreksi primer masih belum diketahui. Kami melaporkan kasus seorang anak laki-laki berusia 11 tahun dirawat dengan sianosis sejak lahir, dyspneu on effort, keterlambatan 
pertumbuhan, masalahbelajar,skoliosis, mikropenis, hipertorisme, exopthalmos, dismorphism wajah, cryptochidism, dan major aorto-pulmonary collateral. Pasien menjalani pemeriksaan ekokardiografi dan menunjukkan malalignment VSD dengan aorta 48\%, stenosis pulmonal kritis, ukuran arteri pulmonal menguntungkan untuk koreksi primer. Kateterisasi jantung menunjukkan fallot klasik dengan arteri koroner normal dan major arteri collateral aortopulmonary (MAPCA) yang timbul. Pasien menjalani embolisasi koil perkutan sesaat sebelum operasi. Ada masalah selama induksi, ahli anestesi sulitmenempatkan ETT karena ditemukan membran yang menutupi trakea.Median sternotomi dilakukan dan penjepitan silang aorta tercapai, atriotomi dilakukan dengan benar dan ada paparan VSD yang tidak selaras. Arteriotomi pulmonal longitudinal dibuat untuk mengekspos stenosis infundibular. Infundibulektomi dilakukan dan merekonstruksi MPA dengan patch perikardial. VSD ditutup menggunakan patch PTFE. Pasien dipindahkan ke ICU sesudahnya. Ekokardiografi pasca operasi menunjukkan hasil yang baik, dan 15 hari setelah operasi pasien keluar. Kami menyimpulkan bahwa koreksi primer TOF dengan MAPCA dan dugaan Sindrom Noonan dilakukan dengan sukses.

\section{INTRODUCTION}

Tetralogy of Fallot was first described by Niels Stenson in 1671, although William Hunter elegantly illustrated its precise anatomical description at St Georges Hospital Medical School in London in 1784: “...the passage from the right ventricle into the pulmonary artery, which should have admitted a finger, was not so wide as a goose quill; and there was a hole in the partition of the two ventricles, large enough to pass the thumb from one to the other. The greatest part of the blood in the right ventricle was driven with that of the left ventricle into the aorta, or great artery, and so lost all the advantage which it ought to have had from breathing". ${ }^{1,2}$ His description of a large outlet ventricular septal defect together with subpulmonary and pulmonary valve stenosis and its resulted physiology was refined by Etienne-Louis Fallot in 1888 in his description of L'anatomie pathologique de la maladie bleu, but the term tetralogy of Fallot (a tetrad of (i) ventricular septal defect with (ii) over-riding of the aorta, (iii) right ventricular outflow obstruction, and (iv) right ventricular hypertrophy) was attributed to Canadian Maude Abbott in 1924. ${ }^{3}$

$3.5 \%$ of all infants born with congenital heart disease have tetralogy of Fallot, corresponding to one in 3600 or 0.28 every 1000 livebirths, with males and females affected equally. 4 The ventricular septal defect is almost always large and non-restrictive in the tetralogy of Fallot, ensuring that the pressure is equal in the two ventricles. Consequently, the loud systolic murmur typical in affected infants originates from dynamic narrowing of the right ventricular outflow tract. The direction and magnitude of flow through the defect depend on severity of obstruction of the right ventricular outflow tract. If obstruction to the right ventricular outflow is severe or if there is atresia, a large right-toleft shunt with low pulmonary blood flow and severe cyanosis requiring intervention at birth are present. ${ }^{4,5}$

However, most patients have adequate pulmonary blood flow at birth but there is increasing cyanosis during the first few weeks and months of life. In countries with welldeveloped paediatric cardiac services, severe cyanosis, recurrent hypercyanotic spells, squatting, and other consequences of severely reduced pulmonary blood flow are rare today. It is because a diagnosis is seldom delayed and infants undergo palliative procedures or frequently complete repair within the first few days, weeks, or months of life. Temporary treatment with propranolol, which decreases right ventricular hypercontractility and heart rate and increases systemic vascular resistance, is sometimes used to reduce the incidence of hypercyanotic spells before surgery. Although an experienced paediatrician or cardiologist usually suspect the diagnosis clinically; transthoracic cross-sectional echocardiography provides a comprehensive description of the intracardiac anatomy. With the exception of patients with major aortopulmonary collateral arteries and rare cases in whom an echocardiographic assessment is incomplete, any other diagnostic 
investigations (e.g., cardiac catheterization) are now rarely performed before palliative or corrective surgery. 2,6

Before the advance of surgical intervention, More than $50 \%$ of patients with tetralogy of Fallot died in the first few years of life, and it was unusual for a patient to survive longer than 30 years. ${ }^{3}$ Nowadays, almost all those born with this disease in all its variants can expect to survive with surgical correction and reach adult life. Since the first reported intracardiac repair of the tetralogy in 1955, the age of patients receiving primary corrective surgery has gradually decreased, with some units advocating surgery at diagnosis, even within the first few days of life. Most centres prefer to operate on children aged 3-6 months, preserving earlier open-heart surgery for those presenting with severe cyanosis or hypercyanotic spells. Some centres continue to offer surgical palliation by constructing a systemic-to-pulmonary arterial shunt, balloon dilation, or placement of a stent in the right ventricular outflow, in neonates and young infants, thereby deferring intracardiac repair. ${ }^{2,3,7}$

Noonan syndrome is a common genetic disorder characterized by facial anomalies, congenital heart defect, short stature, webbed neck, chest deformities and undescended testes. ${ }^{8,9}$ Noonan syndrome is an autosomal dominant, variably expressed, and multisystem disorder with an estimation of 1 in 1000-2500. It was characterized by Jacqueline Noonan, who reported nine patients with pulmonary valve stenosis, small stature, hypertelorism, mild intellectual disability, ptosis, undescended testes, and skeletal malformations. ${ }^{10}$ In developing countries, diagnosed genetic syndromes associated with heart defect have not been covered by health insurance, yet the primary repair outcome is still unknown. Therefore, a purpose of reporting this case was to emphasize the outcome of surgical correction of isolated pulmonary valve stenosis with Noonan syndrome because the outcome remains unknown.

\section{CASE DESCRIPTION \\ Patient information}

An 11-year-old boy admitted with cyanosis since birth, dyspnoea on effort, growth delay, learning problems, scoliosis (Figure 1), micropenis (Figure 2), hypertelorism (Figure 3), exophthalmos (Figure 3), facial dysmorphism (Figure 3), cryptorchidism, and major aortopulmonary collaterals. A consent was taken from a legal guardian to study and publish this case.

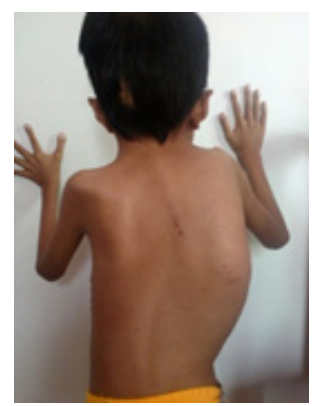

Figure 1. Scoliosis

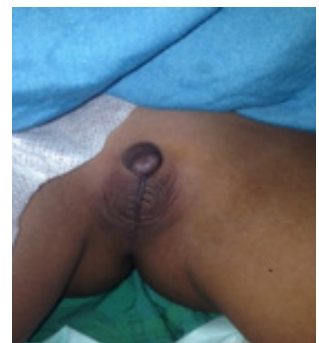

Figure 2. Micropenis 


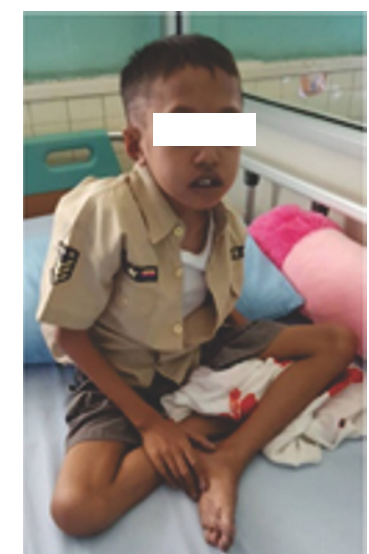

Figure 3. Exophtalmos, Facial dysmorphism and Hypertelorism

\section{Diagnostic methods}

The patient underwent an echocardiographic study. It showed VSD malalignment with overriding aorta of $48 \%$, critical pulmonary stenosis with MaxPG $30.62 \mathrm{mmHg}$, and size of pulmonary arteries was favourable for primary repair according to the kirklin table. $9.3 \mathrm{~mm}$ for the LPA and 1.12 for RPA. Cardiac catheterization presented classic Fallot with normal coronary arteries and major aortopulmonary collateral arteries (MAPCA) arising (Figure 4). However, the patient has not tested for karyotyping to define the syndrome he had with his condition.
The patient underwent percutaneous coil embolization just before surgery was performed. There were several problems during the induction, the anaesthesiologist had trouble placing endotracheal tube (ET) because there was membrane-like covering the trachea. The operation used median sternotomy, the thymus was excised, and the pericardium was preserved. Heparin was administered before arterial cannulation until the targeted ACT was accomplished. Aortic and bicaval venous cannulation was performed. Cardiopulmonary bypass was initiated with moderate hypothermia.

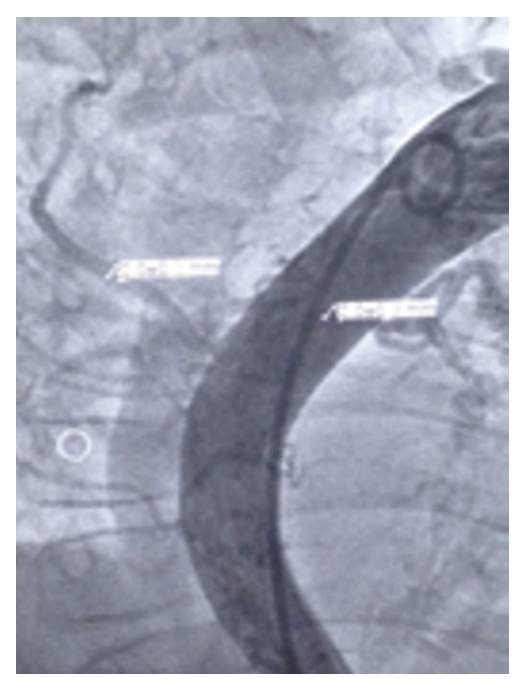

Figure 4. Cardiac catheterization showed classic fallot with normal coronary arteries and major aortopulmonary collateral arteries (MAPCA) arising 
This study used crystalloid cardioplegia delivered by using antegrade route. After the aortic was crossclamped and cardioplegia was delivered, the heart suddenly stopped. Right Atriotomy was performed, and left ventricular vent was inserted via PFO. VSD was examined about $1.5 \mathrm{~cm}$, and there was a hypertrophic segment which was muscle bundles obstructing RVOT. A longitudinal pulmonary arteriotomy was made into RVOT. Infundibulectomy was performed carefully to avoid excessive resection. Furthermore, VSD was closed by using $0.4 \mathrm{~mm}$ Gore-Tex patch with continuous 5-0 prolene sutures. A transannular patch was placed into the pulmonary artery previously incised into RVOT by using a pericardial patch, followed by PFO and RA closure.

\section{Follow-up and outcome}

Transoesophageal echocardiographic postoperative showed that there was no residual flow through the VSD. Pulmonary valve gradient became Trivial PR. The patient was transferred to an ICU afterward. ABP showed 85/45 (55), heart rate of $119 \mathrm{x} / \mathrm{m}$ sinus rhythm with dobutamine support. Total CPB time was 170 minutes and the aortic cross clamp time was 79 minutes.

The post-operative problem found a low cardiac output syndrome due to right ventricular failure. The symptoms were included low blood pressure, oliguria, and metabolic acidosis. Right pleural effusion happened due to RV failure. Chest tube insertion to drainage pleural space and peritoneal dialysis was performed to solve these problems. In POD+5, peritoneal dialysis, and a chest tube were removed. In POD +7 , the patient was moved in to the intermediate room. In POD+14, the patient was discharged from the hospital.

\section{DISCUSSION}

Tetralogy of Fallot (TOF) is a complex congenital heart disease including four abnormalities: ventricular septal defect (VSD), pulmonary stenosis (PS), right ventricular hypertrophy (RVH), an overriding aorta. ${ }^{3}$ Cyanotic heart defect can develop Aorto- pulmonary collateral (APCA) to supply under perfused pulmonary bed. Genetic syndromes can occur in $20 \%$ of patients with TOF. ${ }^{11,12}$ Noonan syndrome is a common genetic disorder characterized by facial anomalies, congenital heart defect, short stature, webbed neck, chest deformities and undescended testes.10 Noonan syndrome (NS) is an autosomal dominant disorder with vast heterogeneity in clinical and genetic features.13 Congenital heart defect associated with Noonan syndrome usually isolated pulmonary valve stenosis, but Noonan JA in 1963 stated that a combination of subaortic stenosis and pulmonary stenosis is a possible variant of Noonan syndrom. ${ }^{9}$

Primary surgical repair of TOF was first described in $1954 .^{2}$ This procedure uses ventriculotomy of right ventricular wall to approach the right ventricular outflow tract obstruction (RVOTO). In this case, this study used a transpulmonary to approach RVOTO because ventriculotomy and aggressive RVOTO relief could cause residual lesions resulted in late morbidity and mortality. This study used transannular patch (TAPs) because the size of the PA was small. Patients with TAPs were associated with pulmonary regurgitation, like this patient. ${ }^{14}$

Regarding post-operative complications, the most common complication was pulmonary regurgitation (PR), incidences of moderate to severe PR was (37.1\%). ${ }^{15}$ In a study by Khan et al., postoperative incidence of PR was $25 \%{ }^{16}$ In our transoesophageal echocardiographic post-operative study showed that there was Trivial PR. Pulmonary valve regurgitation after repair of ToF was relatively well tolerated in the short term, partly because the hypertrophied right ventricle usually adapts to the altered hemodynamic load. ${ }^{17}$ Pulmonary insufficiency is well tolerated for the first few years, but it may result a chronically dilated right ventricle. Patients with isolated congenital pulmonary regurgitation are known to remain asymptomatic for up to 20 years, but thereafter freedom from symptoms declines rapidly with time. ${ }^{4}$

Surgical complication of TOF can occur both in the immediate and late post-operative periods, 
including RV diastolic restriction. ${ }^{2,4} \mathrm{RV}$ diastolic restriction can occur in a face of an apparently adequate repair with preserved ventricular systolic function. ${ }^{4}$ In this case, the post-operative problem found a low cardiac output syndrome due to right ventricular failure; the symptoms included low blood pressure, oliguria, and metabolic acidosis. Also, right pleural effusion happened due to RV failure which was often transient because in POD+7 the problem was solved by placing chest tube and peritoneal dialysis in $\mathrm{POD}+5$.

Overall survival following TOF repair has been significantly improved in recent years after the early primary repair of tetralogy of Fallot was found in the 1970s, reflecting the treatment evolution of all forms of congenital heart disease. There was enthusiasm regarding the decreased operative mortality and the near-normal life expectancy for post-repair survivors, but it was tempered by remaining late morbidity and rare sudden death in a long term. ${ }^{14,17}$ However, primary repair tetralogy of Fallot with possibly Noonan syndrome has not been reported yet. Results of surgical correction of isolated pulmonary valve stenosis with Noonan syndrome remains unknown. Most patients presenting for surgery will have unfavourable morphology of the pulmonary valve. Otherwise, balloon valvotomy in the current era is the primary choice. Elective repair in patients greater than 55 days of age, irrespective the patient's size, can be safely performed without any increase in reintervention rates. ${ }^{18}$

\section{CONCLUSION}

Successful surgical treatment in primary repair tetralogy of Fallot with suspected Noonan syndrome was conducted. After 14 days the patient was discharged although postoperative care with low cardiac output syndrome, and right ventricular failure occurred. However, scoliosis made postoperative rehabilitation become slower.

\section{CONFLICT OF INTEREST}

The authors have none to declare.

\section{ACKNOWLEDGEMENT}

The authors have none to declare.

\section{REFERENCES}

1. Steno N. Anatomicus regij Hafniensis Embryo Monstro affinis Parisiis dissectus. Acta Medica Et Philosophiă, Hafminsiă 1671; 1: 200-5

2. Worku D, Allen R. Tetralogy of Fallot: Origins, management and outcomes. European Journal of Experimental Biology. 2020;10(3):1-5.

3. Boyer R, Kim HJ, Krishnan R. Management of unoperated tetralogy of Fallot in a 59-year-old patient. Journal of Investigative Medicine High Impact Case Reports. 2020;8:1-3.

4. Anderson RH., Kumar K, Mussatto KA, Redington AN, Tweddel JS. Tetralogy of Fallot with pulmonary stenosis. In: Wernovsky G, editor. Anderson' s Pediatric Cardiology. 4th ed. Philadelphia: Churchill Livingstone, an imprint of Elsevier Ltd.; 2020. p. 75173.

5. Shetkar SS, Kothari SS. Intermittent' restrictive ventricular septal defect in tetralogy of Fallot. Annals of Pediatric Cardiology. 2015;8(1):80-1.

6. Zipes DP, Libby P, Bonow RO, Mann DL, Tomaselli GF. Tetralogy of Fallot (including tetralogy with pulmonary atresia). In: BRAUNWALD E, editor. Braunwald's Heart Disease: A Textbook of Cardiovascular Medicine. 11th ed. Philadelphia: Elsevier Inc.; 2019. p. 1544-7.

7. Rahmath MRK, Boudjemline Y. Tetralogy of Fallot will be treated interventionally within two decades. Pediatric Cardiology. 2020;41(3):539-45.

8. Linglart L, Gelb BD. Congenital heart defects in Noonan syndrome: Diagnosis, management, and treatment. American Journal of Medical Genetics Part C Seminars in Medical Genetics. 2020;184(1):73-80.

9. Noonan JA, Ehmke DA. Associated noncardiac malformations in children with congenital heart disease. The Journal of Pediatrics. 1963;63:468-70. 
10. Natraj Setty HS, Shankar S, Patil R, Jadhav S, Yeriswamy MC, Reddy B, et al. Combined cardiac anomalies in Noonan syndrome: A case report. International Journal of Surgery Case Reports. 2020;72:32-6.

11. Michielon G, Marino B, Formigari R, Gargiulo G, Picchio F, Digilio MC, et al. Genetic syndromes and outcome after surgical correction of tetralogy of Fallot. The Annals of Thoracic Surgery. 2006;81(3):968-75.

12. Kim HS, Grady RM, Shahanavaz S. Isolated major aortopulmonary collateral as the sole pulmonary blood supply to an entire lung segment. Case Reports in Cardiology. 2017;2017:1-3.

13. Tafazoli A, Eshraghi P, Koleti ZK, Abbaszadegan M. Noonan syndrome-a new survey. Archives of Medical Science. 2017;13(1):215-22.

14. van der Ven JPG, van den Bosch E, Bogers AJCC, Helbing WA. Current outcomes and treatment of tetralogy of fallot. F1000Research. 2019;8:1-15.

15. Waqar T, Riaz MU, Mahar T. Tetralogy of fallot repair in patients presenting after infancy: A single surgeon experience. Pakistan Journal of Medical Science. 2017;33(4):984-7.

16. Khan I, Tufail Z, Afridi S, Iqbal M, Khan T, Waheed A. Surgery for tetralogy of Fallot in adults: early outcomes. Brazilian Journal of Cardiovascular Surgery. 2016;31(4):3003.

17. Karamlou T, McCrindle BW, Williams WG. Surgery Insight: Late complications following repair of tetralogy of Fallot and related surgical strategies for management. Nature Clinical Practice Cardiovascular Medicine. 2006;3(11):611-22.

18. Cunningham MEA, Donofrio MT, Peer SM, Zurakowski D, Jonas RA, Sinha P. Optimal timing for elective early primary repair of tetralogy of Fallot: Analysis of intermediate term outcomes. The Annals of Thoracic Surgery. 2017;103(3):845-52.. 